\title{
The Prediction Factors of Pre-XDR and XDR-TB among MDR-TB Patients in Northern Thailand
}

\section{Risara Jaksuwan1, Jayanton Patumanond2, Prasit Tharavichikul ${ }^{3}$, Charoen Chuchottaworn4, Pattana Pokeaw ${ }^{5}$, Jongkolnee Settakorn ${ }^{*}$}

${ }^{1}$ Clinical Epidemiology Unit, Faculty of Medicine, Chiang Mai University, Chiang Mai, Thailand

${ }^{2}$ Faculty of Medicine, Thammasat University, Bangkok, Thailand

${ }^{3}$ Department of Microbiology, Faculty of Medicine, Chiang Mai University, Chiang Mai, Thailand

${ }^{4}$ Division of Respiratory Medicine, Chest Disease Institute, Nonthaburi, Thailand

${ }^{5}$ Office of Disease Prevention and Control 10, Chiang Mai, Thailand

${ }^{6}$ Department of Pathology, Faculty of Medicine, Chiang Mai University, Chiang Mai, Thailand

Email: *jsettakorn@gmail.com

How to cite this paper: Jaksuwan, R., Patumanond, J., Tharavichikul, P., Chuchottaworn, C., Pokeaw, P. and Settakorn, J. (2018) The Prediction Factors of Pre-XDR and XDR-TB among MDR-TB Patients in Northern Thailand. Journal of Tuberculosis Research, 6, 36-48.

https://doi.org/10.4236/jtr.2018.61004

Received: December 7, 2017

Accepted: March 4, 2018

Published: March 7, 2018

Copyright $\odot 2018$ by authors and Scientific Research Publishing Inc. This work is licensed under the Creative Commons Attribution International License (CC BY 4.0).

http://creativecommons.org/licenses/by/4.0/

\begin{abstract}
Background: Molecular diagnosis based on the detection of mutations conferring genetic drug resistance is useful for early diagnosis and treatment of Pre-XDR and XDR-TB patients. However, the study of mutation as a marker to predict Pre-XDR and XDR-TB is rare. Methods: Thirty-four Mycobacterium tuberculosis (MTB) isolates from $\mathrm{MDR}$, Pre-XDR and XDR-TB patients in the upper north of Thailand, who had been identified for drug susceptibility using the indirect agar proportion method from 2005-2012, were examined for genetic site mutations of $k a t G$, $i n h A$, and $a h p C$ for isoniazid (INH) drug resistance, $r p o B$ for rifampicin (RIF) drug resistance, gyrA for ofloxacin (OFX), and rrs for kanamycin (KAN). Associations between resistant genes and Pre-XDR and XDR-TB in the MDR patients were performed using exact probability tests. Univariable logistic regression was used to quantify the strength of association between the gene mutation with Mycobacterium tuberculosis and the prevalence of Pre-XDR and XDR-TB in the MDR patients. Results: The mutations in the region of the $r p o B$ gene at codon 445 (C445T) in the Pre-XDR or XDR-TB patients were significantly 20.6 times more prevalent among the MDR-TB patients. The inh $A$ gene mutation at codon 114 (T114G) was also significantly 8.1 times more prevalent. Conclusion: The findings can be used to predict the odds of Pre-XDR and XDR-TB in MDR-TB patients, as a guide for prevention and treatments.
\end{abstract}

\section{Keywords}

Prediction, Tuberculosis, Drug Resistance, MDR-TB, XDR-TB 


\section{Introduction}

Extensively drug-resistant (XDR) tuberculosis (TB) has emerged as a major threat to global TB control. Mycobacterium tuberculosis XDR strains are resistant to rifampin, isoniazid, fluoroquinolone, and any of the second-line injectable agents, including amikacin (AMK), kanamycin (KAN), and capreomycin (CAP) [1]. XDR-TB is usually developed from multidrug-resistant (MDR) TB, which is resistant to rifampin and isoniazid. MDR-TB typically requires two years of treatment with second-line drugs, which is more expensive and more toxic than first-line drugs [2] [3]. The low rate of diagnosis and diagnostic delay, the limited access to second-line drugs, and the poor adherence of MDR-TB patients have mainly led to the emergence of XDR-TB [4]. Most of the XDR-TB and Pre-XDR-TB patients in China were new cases, indicating the transmission of resistant strains [5] [6]. In 2016, Thailand had 80 MDR-TB patients. Of these cases, 20 were on treatment for XDR-TB and 60 were on MDR-TB and Pre-XDR-TB medication [7]. All of them are difficult to treatment.

The cure rate for MDR-TB patients is 50\% - 60\%, compared with $95 \%$ - $97 \%$ of the patients with drug-susceptible TB [8]. As a result, MDR-TB and XDR-TB have emerged as significant threats to global TB control [9]. The emergence of XDR-TB strains is a reflection of poor tuberculosis management and control, and this situation should be considered as an urgent global health problem, especially in developing countries and those lacking resources [10].

Our study aimed to ascertain the risk factors of gene mutation that are associated with the development of Pre-XDR and XDR-TB. The rapid diagnosis of these resistant cases is urgently needed and is useful for treatment. In the future, molecular diagnosis will involve MDR-TB and XDR-TB detection, which is also useful for predicting Pre-XDR and XDR-TB and for monitoring treatment.

\section{Material and Methods}

\subsection{Study Design}

This study was a retrospective study of MDR-TB and XDR-TB M. tuberculosis isolates involving TB patients during 2005-2012 at the Office of Disease Prevention and Control Region 10 (DPC 10) in the north of Thailand as shown in Figure 1. The DPC 10 laboratory is a Regional TB Laboratory covering TB patient treatment from eight provinces in the upper north of Thailand, which can provide M. tuberculosis (MTB) cultures, identification, and Drug Susceptibility Tests (DST) for first- and second-line drugs. The MTB isolates were subcultured, then tested for phenotypes for first- and second-line drug resistance to isoniazid (INH), rifampicin (RIF), ofloxacin (OFX), and kanamycin (KAN) at DPC 10. Further, genetic site mutation for drug resistance in the corresponding resistant gene (katG, inhA, ahpC, rpoB, gyrA and rrs) was performed at Macrogen in Korea. Medical records were retrospectively reviewed for demographic data, diagnosis, and laboratory identification and DST results. 


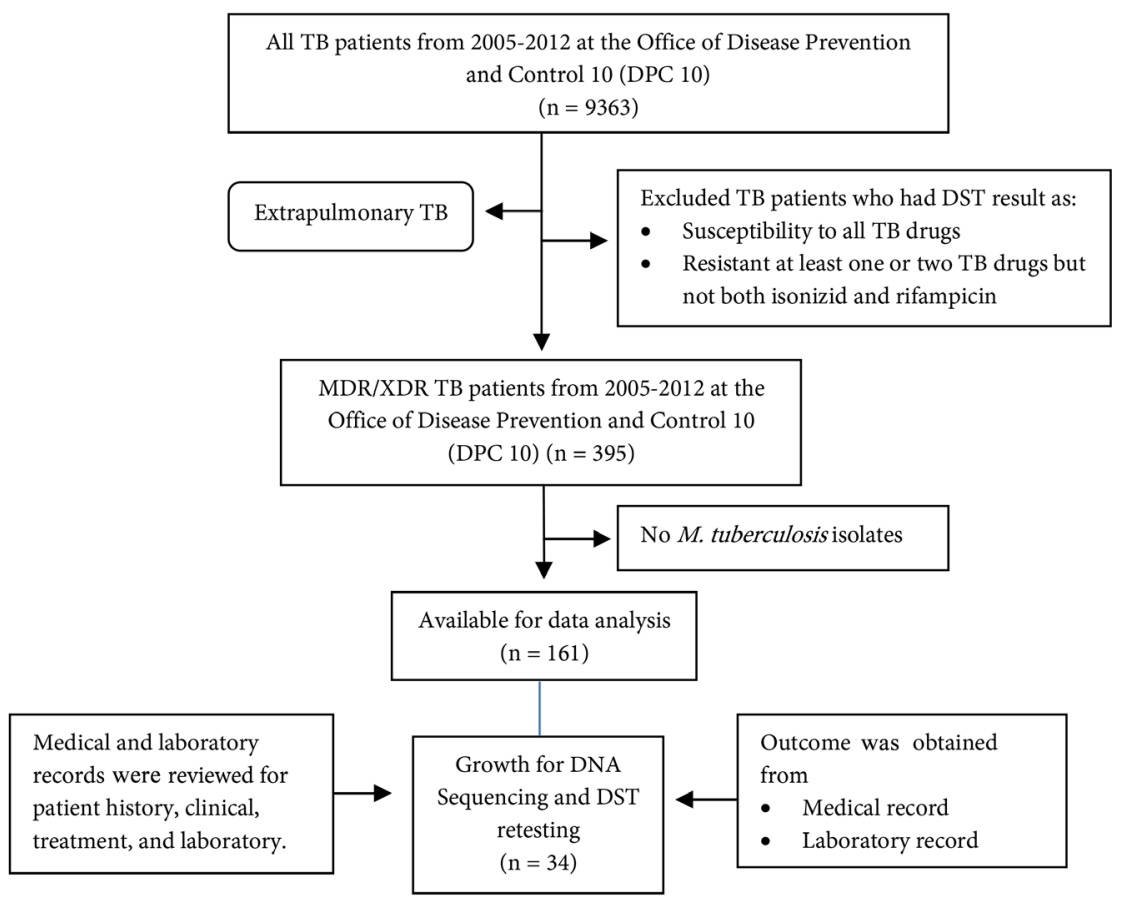

Figure 1. Study flow.

\subsection{Mycobacterial Isolates}

161 MTB multidrug and extensive drug resistant strain isolates from TB patients during 2005-2012 were subcultured from collections at DPC 10 received from 8 hospitals in the upper north of Thailand. Only 34 isolates were able to grow in 5 $\mathrm{ml}$ of 7H9 broth supplemented with PANTA and 3\% Ogawa. Samples were collected from individual TB patients who presented with the initial treatment status.

\subsection{Drug Susceptibility Testing}

Phenotypes testing on first and second line anti-tuberculous drugs (INH, RIF, OFX, and KAN) were performed on 34 isolates of $M$. tuberculosis, using the proportion method on LJ medium [11]. DST was completed according to the WHO guideline for DST testing for first- and second-line anti-tuberculosis drugs for DOTS-plus [12]. DST was determined using the indirect agar proportion method which, was performed on an LJ medium supplemented individually with anti-TB drugs, which included INH $(0.2 \mu \mathrm{g} / \mathrm{ml})$, RIF $(40.0 \mu \mathrm{g} / \mathrm{ml})$, OFX $(2.0$ $\mu \mathrm{g} / \mathrm{ml})$, and $\mathrm{KAN}(30 \mu \mathrm{g} / \mathrm{ml})$.

\subsection{DNA Extraction}

34 isolates were grown on solid media (Löwenstein-Jensen and OGAWA), and chromosomal DNA was extracted using the commercial kit method with MolecuTech REBA MTB-MDR 2011. The purified DNA pellet was stored at $4^{\circ} \mathrm{C}$ until use.

\subsection{Sequencing Method}

Six loci were amplified by PCR: $k a t G$, inh $A$, and $a h p C$ (INH); rpoB (RIF); gyr $A$ 
(OFX); and rrs (KAN) at Macrogen. Genetic site mutations in the corresponding resistance gene ( $k a t G$, inhA, ahpC, rpoB, gyrA, and rrs) were performed using Macrogen molecular laboratory outsources. The primers are presented in Table 1 [4] [13] [14]. The result of sequencing was then subjected to comparison and analysis.

\subsection{Analysis}

The sequencing data produced by the ABI 3730xl DNA analyzer were reviewed for confidence levels with an $\mathrm{ABI}$ sequence scanner, and chromatograms were analyzed for the presence or absence of mutations by comparison with published sequences of H37Rv. The data on clinical patients, resistant genes, genetic site mutation, and phenotype were compiled using the Excel 2010 database. Statistical analysis was performed using a statistical software package. The baseline characteristics of demographic data, treatment outcome and the genetic site mutation were presented using frequency and percentage. The associations between the demographic data, treatment outcome, resistant gene and MDR, Pre-XDR, and XDR were evaluated using exact probability tests. Univariable logistic regression was used to quantify the strength of the association between the demographic data, the gene mutation with Mycobacterium tuberculosis and the prevalence of Pre-XDR and XDR-TB among the MDR-TB patients.

Table 1. Primers used for sequencing.

\begin{tabular}{|c|c|c|c|c|c|}
\hline Gene & Primer & Nucleotide sequencing ( $5^{\prime}$ to $3^{\prime}$ ) & $\begin{array}{l}\text { Product } \\
\text { size }(\mathrm{pb})\end{array}$ & $\operatorname{Temp}\left({ }^{\circ} \mathrm{C}\right)$ & Reference \\
\hline katG & $\begin{array}{l}\text { MtkatGf } \\
\text { MtkatGr }\end{array}$ & $\begin{array}{l}\text { ACCCGAGGCTGCTCCGCTGG } \\
\text { CAGCTCCCACTCGTAGCCGT }\end{array}$ & 168 & $\begin{array}{c}94^{\circ} \mathrm{C}-20 \mathrm{~s} \\
50^{\circ} \mathrm{C}-20 \mathrm{~s} 70 \text { cycles } \\
72^{\circ} \mathrm{C}-20 \mathrm{~s}\end{array}$ & $\begin{array}{l}\text { Afanas'ev } \\
\text { MV, } 2007\end{array}$ \\
\hline inh $A$ & $\begin{array}{l}\text { MtfabGf } \\
\text { MtfabGr }\end{array}$ & $\begin{array}{c}\text { GCCTCGCTGGCCCAGAAAGG } \\
\text { CTCCGGATCCACGGTGGGT }\end{array}$ & 320 & $\begin{array}{c}94^{\circ} \mathrm{C}-20 \mathrm{~s} \\
56^{\circ} \mathrm{C}-20 \mathrm{~s} 70 \text { cycles } \\
72^{\circ} \mathrm{C}-20 \mathrm{~s}\end{array}$ & $\begin{array}{l}\text { Afanas'ev } \\
\text { MV , } 2007\end{array}$ \\
\hline $\operatorname{ahpC}$ & $\begin{array}{l}\text { ahpC1 F } \\
\text { ahpC2 R }\end{array}$ & $\begin{array}{l}\text { GCCTGGGTGTTCGTCACTGGT } \\
\text { CGCAACGTCGACTGGCTCATA }\end{array}$ & 359 & $\begin{array}{c}95^{\circ} \mathrm{C}-40 \mathrm{~s} 15 \mathrm{~min} \\
\text { (start) } \\
94^{\circ} \mathrm{C}-40 \text { s } 30 \text { cycles } \\
57^{\circ} \mathrm{C}-40 \text { s } 1 \mathrm{~min} \\
72^{\circ} \mathrm{C}-40 \mathrm{~s} 15 \mathrm{~min} \\
\text { (final) }\end{array}$ & $\begin{array}{l}\text { Valvatne H, } \\
2009\end{array}$ \\
\hline$r p o B$ & $\begin{array}{l}\text { MtrpoBf } \\
\text { MtrpoBr }\end{array}$ & $\begin{array}{l}\text { GAGGCGATCACCGCAGAC } \\
\text { GGTACGGCGTTTCGATGAAC }\end{array}$ & 321 & $\begin{array}{c}94^{\circ} \mathrm{C}-20 \mathrm{~s} \\
59^{\circ} \mathrm{C}-20 \mathrm{~s} 70 \text { cycles } \\
72^{\circ} \mathrm{C}-20 \mathrm{~s}\end{array}$ & $\begin{array}{l}\text { Afanas'ev } \\
\text { MV, } 2007\end{array}$ \\
\hline gyrA & $\begin{array}{l}\text { gyrBA-3F } \\
\text { gyrBA-3R }\end{array}$ & $\begin{array}{l}\text { AAGAGCGCCACCGACATC } \\
\text { CAGCATCTCCATCGCCAA }\end{array}$ & 320 & $\begin{array}{c}95^{\circ} \mathrm{C}-2 \text { min (start) } \\
95^{\circ} \mathrm{C}-30 \text { cycles } 1 \mathrm{~min} \\
65^{\circ} \mathrm{C}-1 \text { min } \\
72^{\circ} \mathrm{C}-1 \text { min } \\
72^{\circ} \mathrm{C}-10 \text { min (final) }\end{array}$ & $\begin{array}{l}\text { Liang L, } \\
2012\end{array}$ \\
\hline rrs & $\begin{array}{l}16 S-2 F \\
16 S-1 R\end{array}$ & $\begin{array}{c}\text { CGTGGCCGTTTGTTTTGTC } \\
\text { TGGTGCTCCTTAGAAAGGAGG }\end{array}$ & & $\begin{array}{c}95^{\circ} \mathrm{C}-2 \text { min (start) } \\
94^{\circ} \mathrm{C}-35 \text { cycles } 1 \mathrm{~min} \\
60^{\circ} \mathrm{C}-1 \mathrm{~min} \\
68^{\circ} \mathrm{C}-2 \mathrm{~min} \\
68^{\circ} \mathrm{C}-10 \text { min (final) }\end{array}$ & $\begin{array}{l}\text { Liang L, } \\
2012\end{array}$ \\
\hline
\end{tabular}




\section{Results}

\subsection{Characteristics of MDR-TB and Pre-XDR/XDR-TB}

There was no statistically significant difference $(p<0.05)$ between the characteristic of MDR-TB and Pre-XDR/XDR-TB cases (Table 2).

Table 2. Characteristics of MDR and Pre-XDR/XDR-TB patients.

\begin{tabular}{|c|c|c|c|}
\hline & & n (\%) & \\
\hline Characteristics & $\begin{array}{c}\text { MDR-TB } \\
\mathrm{N}=24\end{array}$ & $\begin{array}{c}\text { Pre-XDR } \\
\text { or } \\
\text { XDR-TB } \\
\text { N-10 }\end{array}$ & $p$-value \\
\hline \multicolumn{4}{|l|}{ Gender } \\
\hline $\begin{array}{l}\text { Male } \\
\text { Female }\end{array}$ & $\begin{array}{l}13(54.2) \\
11(45.8)\end{array}$ & $\begin{array}{l}6(60.0) \\
4(40.0)\end{array}$ & 1.000 \\
\hline \multicolumn{4}{|l|}{ Age (year) } \\
\hline $0-20$ & $1(4.2)$ & $0(0.0)$ & \multirow{5}{*}{0.098} \\
\hline $21-40$ & $9(37.5)$ & $5(50.0)$ & \\
\hline $41-60$ & $11(45.8)$ & $4(40.0)$ & \\
\hline$>60$ & $3(12.5)$ & $1(10.0)$ & \\
\hline Mean (SD) & $44.6(14.5)$ & $43.3(11.5)$ & \\
\hline \multicolumn{4}{|l|}{ Nationality } \\
\hline $\begin{array}{l}\text { Thai } \\
\text { Non-Thai }\end{array}$ & $\begin{array}{c}21(87.5) \\
3(12.5)\end{array}$ & $\begin{array}{l}7(70.0) \\
3(30.0)\end{array}$ & 0.328 \\
\hline \multicolumn{4}{|l|}{ Treatment history } \\
\hline $\begin{array}{l}\text { New } \\
\text { Previous }\end{array}$ & $\begin{array}{l}14(58.3) \\
10(41.7)\end{array}$ & $\begin{array}{l}4(40.0) \\
6(60.0)\end{array}$ & 0.457 \\
\hline \multicolumn{4}{|l|}{ BMI } \\
\hline $\begin{array}{l}<18.5 \\
\geq 18.5 \\
\text { Mean (SD) }\end{array}$ & $\begin{array}{l}11(45.8) \\
13(54.2) \\
18.9(3.3)\end{array}$ & $\begin{array}{c}7(70.0) \\
3(30.0) \\
17.0(3.8)\end{array}$ & 0.270 \\
\hline \multicolumn{4}{|l|}{ Chest x-ray } \\
\hline $\begin{array}{l}\text { Non-cavity } \\
\text { Cavity }\end{array}$ & $\begin{array}{l}14(58.3) \\
10(41.7)\end{array}$ & $\begin{array}{l}4(40.0) \\
6(60.0)\end{array}$ & 0.457 \\
\hline \multicolumn{4}{|l|}{ Sputum smear } \\
\hline $\begin{array}{l}\text { Negative } \\
\text { AFB 1+ } \\
\text { AFB 2+ } \\
\text { AFB 3+ }\end{array}$ & $\begin{array}{l}4(16.7) \\
7(29.2) \\
5(20.8) \\
8(33.3)\end{array}$ & $\begin{array}{l}1(10.0) \\
3(30.0) \\
1(10.0) \\
5(50.0)\end{array}$ & 0.836 \\
\hline \multicolumn{4}{|l|}{ Comorbidity } \\
\hline $\begin{array}{l}\text { No } \\
\text { Yes }\end{array}$ & $\begin{array}{c}11(91.7) \\
1(8.3)\end{array}$ & $\begin{array}{l}1(10.0) \\
9(90.0)\end{array}$ & 0.061 \\
\hline \multicolumn{4}{|l|}{ Location } \\
\hline ChiangMai & $5(20.8)$ & $3(30.0)$ & \multirow{7}{*}{1.000} \\
\hline ChiangRai & $7(29.2)$ & $3(30.0)$ & \\
\hline Lampang & $2(8.3)$ & $0(0.0)$ & \\
\hline Lamphun & $1(4.2)$ & $0(0.0)$ & \\
\hline Nan & $3(12.5)$ & $1(10.0)$ & \\
\hline Phrae & $5(20.8)$ & $2(20.0)$ & \\
\hline Phayao & $1(4.2)$ & $1(10.0)$ & \\
\hline
\end{tabular}




\subsection{Treatment Patterns of MDR-TB and Pre-XDR/XDR-TB}

The majority of treatments in of the MDR-TB and Pre-XDR/XDR-TB patients were similar that found combination directly observed and self-administered for therapy type, CAT V (I) for treatment pattern, during on treatment more than 24 months in Table 3. The majority of side effects were different in two groups that found minor side effect (75.0\%) in MDR-TB patients but found major side effect (40.0\%) in Pre-XDR or XDR-TB patients in Table 3.

\subsection{Treatment Outcome of MDR-TB and Pre-XDR/XDR-TB}

The treatment outcome resulting as "cure" was observed mainly in MDR-TB (50\%). Cure/successful treatment was found $30 \%$ in Pre-XDR/XDR-TB group with defaulted (30\%) and dead (30\%) as shown in Table 4. However, it is found that $20 \%$ of deaths in Pre-XDR/XDR-TB patients occurred before the initiation of TB treatment.

Table 3. Treatment patterns of MDR and Pre-XDR/XDR-TB patients.

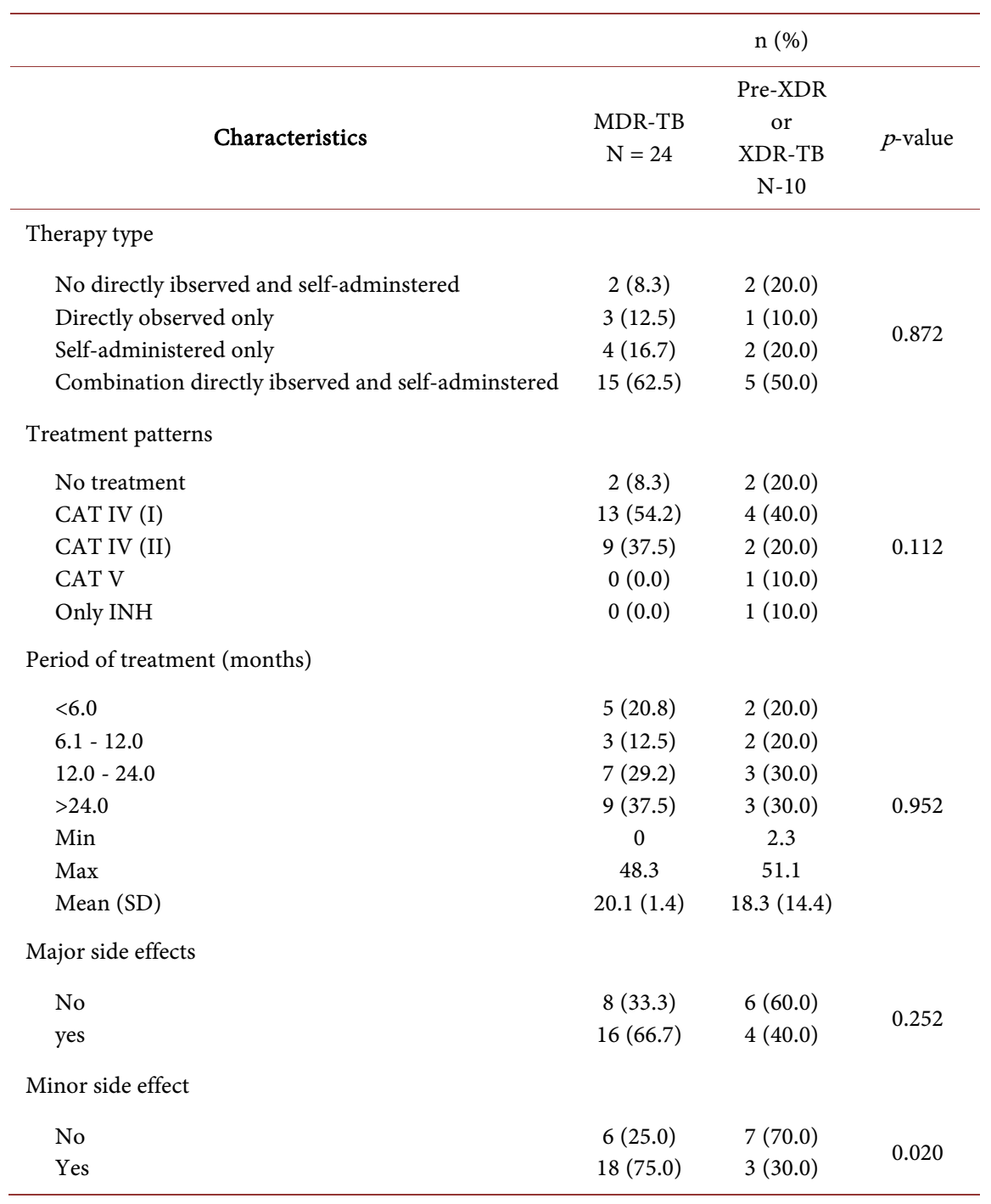


Table 4. Treatment outcome for MDR and Pre-XDR/XDR-TB.

\begin{tabular}{|c|c|c|c|}
\hline & & $\mathrm{n}(\%)$ & \\
\hline Outcome of treatment & $\begin{array}{c}\text { MDR-TB } \\
\mathrm{N}=24\end{array}$ & $\begin{array}{c}\text { Pre-XDR } \\
\text { or } \\
\text { XDR-TB } \\
\text { N-10 }\end{array}$ & $p$-value \\
\hline Treatment outcome & & & 0.697 \\
\hline Cure & $12(50.0)$ & $3(30.0)$ & \\
\hline Complete & $1(4.2)$ & $0(0.0)$ & \\
\hline Failure & $1(4.2)$ & $1(10.0)$ & \\
\hline Dead & $6(25.0)$ & $3(30.0)$ & \\
\hline Defaulted & $4(16.6)$ & $3(30.0)$ & \\
\hline
\end{tabular}

\subsection{MDR-TB, and Pre-XDR/XDR-TB with Gene Mutation Codon}

The analysis was conducted on 34 isolates of which 24 was MDR-TB, 9 Pre XDR and 1 XDR-TB. DNA sequencing was tested following six resistant genes: $k a t G$, inh $A$, $a h p C, r p o B$, gyrA, and $r r s$. The $k a t G$, inh $A$, ahpC, and $r p o B$ indicated resistance to the first-line antibiotic treatment, while gyr $A$ and rrs indicated resistance to the second-line antibiotic treatment. The distribution of MDR, Pre-XDR and XDR-TB by mutation site in $k a t G$, inh $A, \operatorname{ahpC}, r p o B$, gyrA, and rrs gene can be seen in Table 5 and Table 6. The isoniazid (INH) resistant isolates had genetic site mutations within the $k a t G$ gene, inh $A$ gene, and $\operatorname{ahp} C$ gene, which had mutated in many codons (Table 5). The majority of the $k a t G$ gene mutations in MDR-TB had a genetic site mutation in codon 315 (Table 5). There was no mutation in any $k a t G$ codon of the 14 cases in MDR, Pre-XDR/XDR-TB (Table 5). There were two cases of isoniazid (INH) drug resistance that exhibited no mutation to any genetic site on the $k a t G$, inh $A$, and ahpC gene in the MDR-TB patients. Two cases found mutation only a kat $G$ gene in the Pre-XDR-TB patients in our study. Mutation of $r p o B 445$ codon was significantly found in Pre-XDR/XDR-TB isolates (50\%) than in MDR-TB isolates (23.5\%) with the $\mathrm{p}$-value of 0.031 (Table 6).

\subsection{Odds of Pre-XDR/XDR-TB by Clinical Profile and Loci of Gene Mutation}

Our study found that Pre-XDR/XDR-TB patients significantly presented a mutation in the region of the $r p o B$ gene at codon 445 (C445T) 20.6 times than the MDR-TB patients $(P=0.026)$ (Table 7$)$. The results also showed that the prevalence inh $A$ gene mutation at codon $114(\mathrm{~T} 114 \mathrm{G})$ was significantly higher (8.1 times) in the Pre-XDR/XDR-TB patients than in the MDR-TB patients ( $p=$ 0.034) (Table 7). Also the data presented that minor side effect was significantly lower (0.14 times) in the Pre-XDR/XDR-TB patients than in the MDR-TB patients $(p=0.020)$ (Table 7).

The predictive markers in a logistic model (the mutation of the inh $A$ gene at codon 114 , the $r p o B$ gene at codon 445 , the rrs gene at codon 414 and minor 
Table 5. Distribution of MDR-TB, and Pre-XDR-TB/XDR-TB by $k a t G$, inh $A$, and $a h p C$ gene mutation codon.

\begin{tabular}{|c|c|c|c|c|}
\hline Gene mutation codon & $\begin{array}{c}\text { MDR-TB } \\
\text { n (\%) }\end{array}$ & $\begin{array}{c}\text { Pre-XDR } \\
\text { or } \\
\text { XDR-TB } \\
\mathrm{n}(\%)\end{array}$ & Total & $p$-value \\
\hline \multicolumn{5}{|l|}{ katG } \\
\hline No mutation & $10(41.7)$ & $4(40.0)$ & $14(41.2)$ & 0.618 \\
\hline katG315 & $10(41.7)$ & $2(20.0)$ & $12(35.3)$ & 0.211 \\
\hline katG 320 & $1(4.2)$ & $0(0.0)$ & $1(2.9)$ & 0.706 \\
\hline kat $G 300$ & $0(0.0)$ & $1(10.0)$ & $1(2.9)$ & 0.294 \\
\hline katG 302 & $0(0.0)$ & $0(0.0)$ & $1(2.9)$ & 0.294 \\
\hline katG 314 & $1(4.2)$ & $0(0.0)$ & $1(2.9)$ & 0.706 \\
\hline katG 308 & $1(4.2)$ & $2(20.0)$ & $3(8.8)$ & 0.201 \\
\hline katG299 & $0(0.0)$ & $1(10.0)$ & $1(2.9)$ & 0.294 \\
\hline katG 340 & $3(12.5)$ & $1(10.0)$ & $4(11.8)$ & 0.666 \\
\hline kat $G 343$ & $5(20.8)$ & $2(20.0)$ & $7(20.6)$ & 0.670 \\
\hline katG 310 & $1(4.2)$ & $2(20.0)$ & $3(8.8)$ & 0.201 \\
\hline katG 312 & $1(4.2)$ & $3(30.0)$ & $4(11.8)$ & 0.067 \\
\hline \multicolumn{5}{|l|}{$\operatorname{Inh} A$} \\
\hline No mutation & $5(20.8)$ & $2(20.0)$ & $7(20.6)$ & 0.670 \\
\hline $\operatorname{inh} A 14$ & $8(33.3)$ & $3(30.0)$ & $11(32.4)$ & 0.591 \\
\hline $\operatorname{inh} A 25$ & $1(4.2)$ & $0(0.0)$ & $1(2.9)$ & 0.706 \\
\hline $\operatorname{inh} A 78$ & $5(20.8)$ & $3(30.0)$ & $8(23.5)$ & 0.435 \\
\hline $\operatorname{inh} A 81$ & $5(20.8)$ & $2(20.0)$ & $7(20.6)$ & 0.670 \\
\hline $\operatorname{inh} A 84$ & $6(25.0)$ & $3(30.0)$ & $9(26.5)$ & 0.538 \\
\hline $\operatorname{inh} A 86$ & $6(25.0)$ & $2(20.0)$ & $8(25.5)$ & 0.565 \\
\hline $\operatorname{inh} A 94$ & $3(12.5)$ & $0(0.0)$ & $3(8.8)$ & 0.338 \\
\hline inhA 114 & $5(20.8)$ & $6(60.0)$ & $11(32.4)$ & 0.036 \\
\hline \multicolumn{5}{|l|}{$a h p C$} \\
\hline No mutation & $14(58.3)$ & $7(70.0)$ & $21(61.8)$ & 0.406 \\
\hline $\operatorname{ahpC} 10$ & $2(8.3)$ & $2(20.0)$ & $4(11.8)$ & 0.334 \\
\hline ahpC 12 & $2(8.3)$ & $2(20.0)$ & $4(11.8)$ & 0.334 \\
\hline ahpC 20 & $3(12.5)$ & $1(10.0)$ & $4(11.8)$ & 0.666 \\
\hline $\operatorname{ahpC} 22$ & $2(8.3)$ & $1(10.0)$ & $3(8.8)$ & 0.662 \\
\hline$a h p C 75$ & $6(25.0)$ & $1(10.0)$ & $7(20.6)$ & 0.315 \\
\hline ahpC 76 & $5(20.8)$ & $1(10.0)$ & $6(17.7)$ & 0.416 \\
\hline
\end{tabular}

Table 6. Distribution of MDR-TB, and Pre-XDR/XDR-TB by $r p o B$, gyrA and rrs gene mutation codon.

\begin{tabular}{lcccc}
\hline & \multicolumn{3}{c}{ Pre-XDR } \\
Gene mutation codon & $\begin{array}{c}\text { or } \\
\mathrm{n}(\%)\end{array}$ & $\begin{array}{c}\text { XDR-TB } \\
\mathrm{n}(\%)\end{array}$ & Total & \\
& & & \\
& & & \\
\hline -value & \\
No mutation & & & \\
$r p o B 445$ & $4(16.7)$ & $2(20.0)$ & $6(17.7)$ & 0.584 \\
$r p o B 450$ & $3(12.5)$ & $5(50.0)$ & $8(23.5)$ & 0.031 \\
$r p o B 464$ & $5(20.8)$ & $1(10.0)$ & $6(17.7)$ & 0.416 \\
$r p o B 483$ & $6(25.0)$ & $0(0.0)$ & $6(17.7)$ & 0.100 \\
$r p o B 490$ & $2(8.3)$ & $2(20.0)$ & $4(11.8)$ & 0.334 \\
$r p o B 493$ & $5(20.8)$ & $2(20.0)$ & $7(20.6)$ & 0.670 \\
$r p o B 507$ & $2(8.3)$ & $2(20.0)$ & $4(11.8)$ & 0.334 \\
$r p o B 508$ & $7(29.2)$ & $2(20.0)$ & $9(26.5)$ & 0.462 \\
\hline
\end{tabular}




\section{Continued}

\begin{tabular}{lcccc}
\hline gyrA & & & \\
No mutation & $5(20.8)$ & $2(20.0)$ & $7(20.6)$ & 0.670 \\
gyrA 21 & $1(4.2)$ & $0(0.0)$ & $1(2.9)$ & 0.706 \\
gyrA 70 & $2(8.3)$ & $0(0.0)$ & $2(5.9)$ & 0.492 \\
gyrA 87 & $17(70.8)$ & $6(60.0)$ & $23(67.7)$ & 0.409 \\
gyrA 102 & $1(4.2)$ & $0(0.0)$ & $1(2.9)$ & 0.706 \\
gyrA 162 & $10(41.7)$ & $5(50.0)$ & $15(44.1)$ & 0.471 \\
gyrA 187 & $8(33.3)$ & $4(40.0)$ & $12(35.3)$ & 0.502 \\
\hline rrs & & & & \\
No mutation & $16(66.7)$ & $3(30.0)$ & $19(60.2)$ & 0.057 \\
rrs 223 & $2(8.3)$ & $3(30.0)$ & $5(14.7)$ & 0.138 \\
rrs 241 & $1(4.2)$ & $1(10.0)$ & $2(5.9)$ & 0.508 \\
rrs 408 & $5(20.8)$ & $4(40.0)$ & $9(26.5)$ & 0.230 \\
rrs 414 & $2(8.3)$ & $4(40.0)$ & $6(17.7)$ & 0.048 \\
rrs 512 & $1(4.2)$ & $1(10.0)$ & $5(5.9)$ & 0.508 \\
\hline
\end{tabular}

Table 7. Odds of Pre-XDR/XDR-TB by loci of gene mutation.

\begin{tabular}{|c|c|c|c|c|}
\hline Gene & Loci of mutations & Odd ratio & $95 \% \mathrm{CI}$ & $p$-value \\
\hline \multirow{6}{*}{$\operatorname{inh} A$} & No mutation & 1.00 & Reference & - \\
\hline & inhA 14 & 0.66 & $0.10-4.55$ & 0.676 \\
\hline & $\operatorname{inh} A 81$ & 3.00 & $0.14-65.52$ & 0.484 \\
\hline & $\operatorname{inh} A 84$ & 1.23 & $0.09-17.00$ & 0.876 \\
\hline & $\operatorname{inh} A 86$ & 0.60 & $0.04-8.19$ & 0.702 \\
\hline & $\operatorname{inh} A 114$ & 8.12 & $1.17-56.10$ & 0.034 \\
\hline \multirow{4}{*}{$a h p C$} & No mutation & 1.00 & Reference & - \\
\hline & $\operatorname{ahpC} 10$ & 1.88 & $0.17-20.11$ & 0.602 \\
\hline & $a h p C 12$ & 1.88 & $0.17-20.11$ & 0.602 \\
\hline & $a h p C 76$ & 0.51 & $0.05-5.31$ & 0.577 \\
\hline \multirow{7}{*}{ гров } & No mutation & 1.00 & Reference & - \\
\hline & гров 445 & 20.64 & $1.44-295.42$ & 0.026 \\
\hline & $r p o B 450$ & 0.54 & $0.03-8.35$ & 0.659 \\
\hline & гров 483 & 1.51 & $0.08-29.17$ & 0.783 \\
\hline & гров 490 & 0.23 & $0.01-4.59$ & 0.336 \\
\hline & гров 507 & 3.53 & $0.30-41.70$ & 0.317 \\
\hline & гров 508 & 12.23 & $0.20-757.35$ & 0.234 \\
\hline \multirow{6}{*}{ rrs } & No mutation & 1.00 & Reference & - \\
\hline & rrs 223 & 1.85 & $0.15-22.38$ & 0.628 \\
\hline & rrs 241 & 0.70 & $0.01-32.78$ & 0.856 \\
\hline & rrs 408 & 2.17 & $0.28-16.60$ & 0.456 \\
\hline & rrs 414 & 6.90 & $0.77-61.89$ & 0.084 \\
\hline & rrs 512 & 3.68 & $0.17-77.73$ & 0.402 \\
\hline \multirow{2}{*}{$\begin{array}{l}\text { Minor side } \\
\text { effect }\end{array}$} & No minor side effect & 1.00 & Reference & - \\
\hline & Minor side effect & 0.14 & $0.15-22.38$ & 0.020 \\
\hline
\end{tabular}

side effect can be explained $89.6 \%$ the probability of Pre-XDR/XDR-TB among MDR-TB (Figure 2).

\section{Discussion}

The predictors of Pre-XDR/XDR-TB from MDR-TB that will be useful for early treatment need to be identified from the genetic mutation marker. Mutations in 


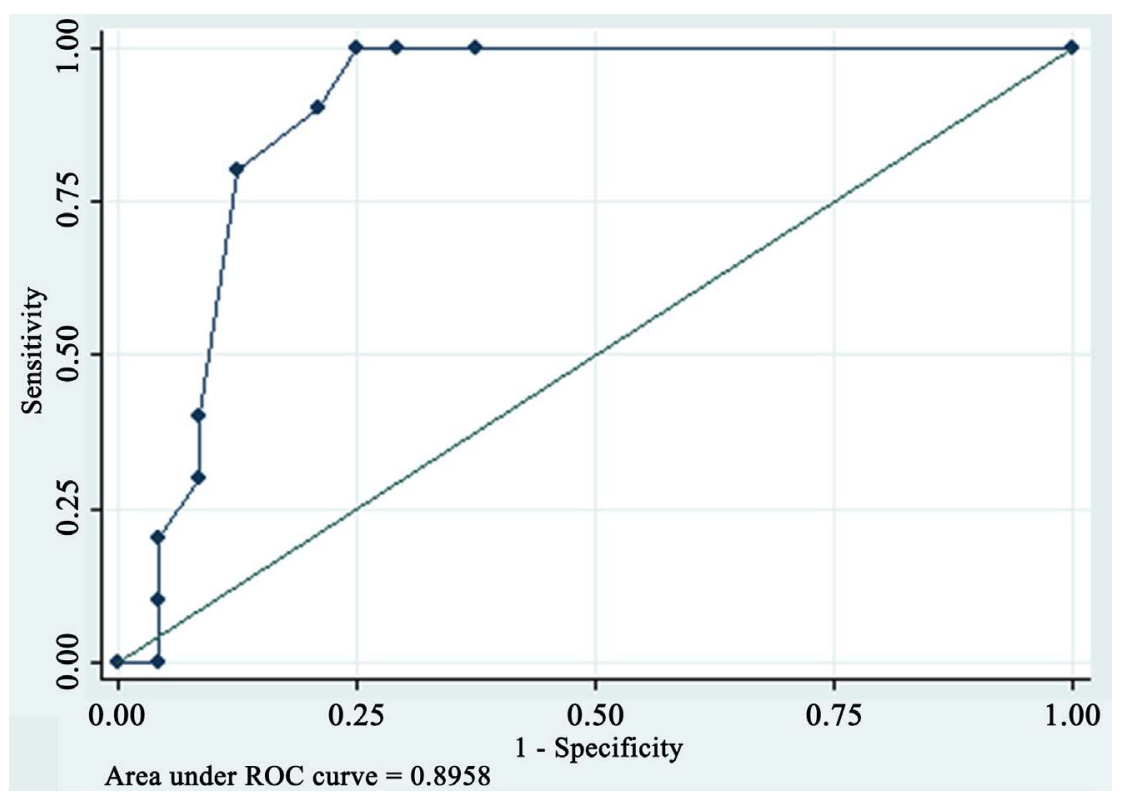

Figure 2. Receiver operating characteristic (ROC) curve of predictive markers of Pre-XDR/XDR-TB among MDR-TB.

the selected genes of $M$. tuberculosis have been used as markers for anti-TB drug resistance. Our results found that DST phenotypic resistance correlated with resistant genes, isoniazid resistance and $k a t G$, inh $A$, $\operatorname{ahpC}$; and rifampicin resistance and $r p o B$.

Gene mutation site in MDR-TB and Pre-XDR/XDR-TB patents: The $r p o B$ gene mutation was a significant factor in terms of increasing the severity of MDR-TB, which may lead to the diagnosis (prediction) of Pre-XDR-TB and XDR-TB in patients. Previous study showed that $31.2 \%$ of the primary MDR-TB patients in China had S531L rpoB mutation [15]. Wang Sheng Fen study further showed that the combination of mutations in gyr $A$, rrs, and tly $A$ could predict Pre-XDR-TB with $68.9 \%$ sensitivity and XDR-TB with $65.9 \%$ sensitivity and $100 \%$ specificity [16].

\subsection{InhA 114 among Pre-XDR/XDR-TB Patients and MDR-TB Patients}

Our study showed that the inhA gene mutation position at 114 (T114G) and the $r p o B$ gene mutation position at 445 (C445T) maybe used as a tool to predict the Pre-XDR/XDR-TB patients. The mutation of T114G or C445T was more likely to be associated with the development to Pre-XDR-TB and XDR-TB among MDR-TB, with the chance of 8.1 and 20.6 times, respectively. In our study, gene mutation in inhA 114 was detected in $82.6 \%$ (19/23) of the MDR and in $17.4 \%$ (4/23) of the Pre-XDR or XDR-TB strains. There have been no previous reports of inhA 114 mutation in MDR-TB and XDR-TB strains; however this could be a case of silent mutation. Mutations of inhA are also commonly found at (-15) [17] [18] [19] [20] among the Mycobacterium tuberculosis drug resistant strains that can be found among TB and MDR-TB patients. 


\subsection{RpoB 445 among Pre-XDR or XDR-TB Patients or MDR-TB Patients}

Many studies have documented that $r p o B 445$ is very specific to rifampicin resistance, which has been used to detect MDR-TB [21] [22] [23]. In our study, gene mutation in $r p o B$ was detected in $85.3 \%$ (29/34) of the MDR and XDR-TB strains and was more likely to be found in Pre-XDR and XDR-TB patients by about 20 times when compared with the MDR-TB patients. One study showed that $r p o B 445$ was a very strong factor in predicting rifampicin resistance [24]. A previous study in Swaziland showed rpoB 445 mutation in MDR-TB patients (79.17\%) [22]. The $r p o B 445$ mutation was also found during the outbreak of MDR-TB in Argentina in 1973 [23]. Previous studies have shown that rpoB445 could predict MDR with high specificity but low sensitivity [19].

\subsection{Minor Side Effect among Pre-XDR/XDR-TB Patients or MDR-TB Patients}

The attention paid for treatment of ADR with minimum modification of treatment regimen that was increased cure rate [25]. Also the previous study in MDR-TB without co-infection with HIV showed ADR was not effect to stop treatment [26]. Minor side effects appeared to have little impact on treatment completion and the conversion to Pre-XDR/XDR-TB because patients tended to visit healthcare providers more often to discuss their side effect concerns, resulting in better continuation of care and treatment which indirectly lowering the conversion to Pre-XDR/XDR-TB.

\section{Conclusion}

In conclusion, our study has found that presence of mutations in inh $A 114$ and rpoB 445 could be an indicator for Pre-XDR and XDR-TB strains among MDR-TB patients in northern Thailand. Prospective results should be done before applying these mutations as markers for Pre-XDR and XDR-TB in this population.

\section{Limitations of This Study}

The limitation of this study was that it was a retrospective study where the evaluation was carried out using only one-fifth isolates that could be subcultured from a total of 161 isolates. The sample size was rather limited. Generalization from this study should be made with caution.

\section{Acknowledgements}

This study was supported by the National Research Council of Thailand and the Faculty of Medicine, Chiang Mai University, Chiang Mai, Thailand. We would like to thank all of the support staff at the Disease Prevention and Control Region 10 (DPC 10), and at Nakornping Hospital, Chiang Rai Hospital, Lampang Hospital, Phayao Hospital, ChiangKan Hospital, Lamphun Hospital, Phrae Hospital, and Nan Hospital. 


\section{References}

[1] World Health Organization (2014) Global Tuberculosis Report 2014. WHO/HTM/ TB/2014.08 ed. World Health Organization, Printed in France.

[2] World Health Organization (2014) Companion Handbook to the WHO Guidelines for the Programmatic Management of Drug-Resistant Tuberculosis. WHO Document Production Services, Geneva.

[3] Ahmad, S. and Mokaddas, E. (2014) Current Status and Future Trends in the Diagnosis and Treatment of Drug-Susceptible and Multidrug-Resistant Tuberculosis. $J$ Infect Public Health, 7, 75-91. https://doi.org/10.1016/j.jiph.2013.09.001

[4] Liang, L., Wu, Q., Gao, L., et al. (2012) Factors Contributing to the High Prevalence of Multidrug-Resistant Tuberculosis: A Study from China. Thorax, 67, 632-638. https://doi.org/10.1136/thoraxjnl-2011-200018

[5] Paramasivan, C.N., Lee, E., Kao, K., et al. (2010) Experience Establishing Tuberculosis Laboratory Capacity in a Developing Country Setting. International Journal of Tuberculosis and Lung Disease, 14, 59-64.

[6] Heysell, S.K. and Houpt, E.R. (2012) The Future of Molecular Diagnostics for Drug-Resistant Tuberculosis. Expert Review of Molecular Diagnostics, 12, 395-405. https://doi.org/10.1586/erm.12.25

[7] World Health Organization ROfS-EA (2016) Joint WHO SEARO-WPRO-HQ "Experience Sharing Workshop on the Introduction of New Drugs for DR-TB Treatment in the WHO South East Asia and Western Pacific Regions" 24th-25th February 2016.

[8] Behera, D. (2010) Expanding DOTS-New Strategies for TB Control? The Indian Journal of Tuberculosis, 57, 63-66.

[9] World Health Organization (2008) Anti-Tuberculosis Drug Resistance in the World: Forth Global Report. The WHO/IUATLD Global Project on Anti-Tuberculosis Drug Resistance Surveillance 2002-2007. WHO, Geneva.

[10] Jain, A. and Dixit, P. (2008) Multidrug-Resistant to Extensively Drug Resistant Tuberculosis: What Is Next? Journal of Biosciences, 33, 605-616.

https://doi.org/10.1007/s12038-008-0078-8

[11] Almeida Da Silva, P.E. and Palomino, J.C. (2011) Molecular Basis and Mechanisms of Drug Resistance in Mycobacterium tuberculosis. Classical and New Drugs. The Journal of Antimicrobial Chemotherapy, 66, 1417-1430. https://doi.org/10.1093/jac/dkr173

[12] Ilina, E.N., Shitikov, E.A., Ikryannikova, L.N., et al. (2013) Comparative Genomic Analysis of Mycobacterium tuberculosis Drug Resistant Strains from Russia. PLoS ONE, 8, e56577. https://doi.org/10.1371/journal.pone.0056577

[13] Afanas'ev, M.V., Ikryannikova, L.N., Il'ina, E.N., et al. (2007) Molecular Characteristics of Rifampicin- and Isoniazid-Resistant Mycobacterium tuberculosis Isolates from the Russian Federation. The Journal of Antimicrobial Chemotherapy, 59, 1057-1064. https://doi.org/10.1093/jac/dkm086

[14] Valvatne, H., Syre, H., Kross, M., et al. (2009) Isoniazid and Rifampicin Resistance-Associated Mutations in Mycobacterium tuberculosis Isolates from Yangon, Myanmar: Implications for Rapid Molecular Testing. The Journal of Antimicrobial Chemotherapy, 64, 694-701. https://doi.org/10.1093/jac/dkp292

[15] Wang, H., Zhang, X., Luo, T., et al. (2014) Prediction of XDR/Pre-XDR Tuberculosis by Genetic Mutations among MDR Cases from a Hospital in Shandong, China. Tuberculosis, 94, 277-281. https://doi.org/10.1016/j.tube.2014.03.005 
[16] Wang, S.F., Zhou, Y., Pang, Y., Zheng, H.W. and Zhao, Y.L. (2016) Prevalence and Risk Factors of Primary Drug-Resistant Tuberculosis in China. Biomedical and Environmental Sciences. BES, 29, 91-98.

[17] Bollela, V.R., Namburete, E.I., Feliciano, C.S., Macheque, D., Harrison, L.H. and Caminero, J.A. (2016) Detection of katG and inhA Mutations to Guide Isoniazid and Ethionamide Use for Drug-Resistant Tuberculosis. International Journal of Tuberculosis and Lung Disease, 20, 1099-1104. https://doi.org/10.5588/ijtld.15.0864

[18] Lee, S.H., Kim, W.S., Choi, Y.D., et al. (2015) Analysis of Mutations in Epidermal Growth Factor Receptor Gene in Korean Patients with Non-small Cell Lung Cancer: Summary of a Nationwide Survey. Journal of Pathology and Translational Medicine, 49, 481-488. https://doi.org/10.4132/jptm.2015.09.14

[19] Kardan Yamchi, J., Haeili, M., Gizaw Feyisa, S., et al. (2015) Evaluation of Efflux Pump Gene Expression among Drug Susceptible and Drug Resistant Strains of $M y-$ cobacterium tuberculosis from Iran. Infection, Genetics and Evolution, 36, 23-26. https://doi.org/10.1016/j.meegid.2015.08.036

[20] Seifert, M., Catanzaro, D., Catanzaro, A. and Rodwell, T.C. (2015) Genetic Mutations Associated with Isoniazid Resistance in Mycobacterium tuberculosis. A Systematic Review. PLOS ONE, 10, e0119628. https://doi.org/10.1371/journal.pone.0119628

[21] Salamon, H., Yamaguchi, K.D., Cirillo, D.M., et al. (2015) Integration of Published Information into a Resistance-Associated Mutation Database for Mycobacterium tuberculosis. The Journal of Infectious Diseases, 211, S50-S57. https://doi.org/10.1093/infdis/jiu816

[22] Sanchez-Padilla, E., Merker, M., Beckert, P., et al. (2015) Detection of Drug-Resistant Tuberculosis by Xpert MTB/RIF in Swaziland. The New England Journal of Medicine, 372, 1181-1182. https://doi.org/10.1056/NEJMc1413930

[23] Eldholm, V., Monteserin, J., Rieux, A., et al. (2015) Four Decades of Transmission of a Multidrug-Resistant Mycobacterium tuberculosis Outbreak Strain. Nature Communications, 6, Article Number: 7119. https://doi.org/10.1038/ncomms8119

[24] Kumar, S. and Jena, L. (2014) Understanding Rifampicin Resistance in Tuberculosis through a Computational Approach. Genomics \& informatics, 12, 276-282. https://doi.org/10.5808/GI.2014.12.4.276

[25] Dela, A.I., Tank, N.K.D., Singh, A.P. and Piparva, K.G. (2017) Adverse Drug Reactions and Treatment Outcome Analysis of DOTS-Plus Therapy of MDR-TB Patients at District Tuberculosis Centre: A Four Year Retrospective Study. Lung India: Official Organ of Indian Chest Society, 34, 522-526. https://doi.org/10.4103/0970-2113.217569

[26] Isaakidis, P., Varghese, B., Mansoor, H., Cox, H.S., Ladomirska, J., Saranchuk, P., et al. (2012) Adverse Events among HIV/MDR-TB Co-Infected Patients Receiving Antiretroviral and Second Line Anti-TB Treatment in Mumbai, India. PloS ONE, 7, e40781. https://doi.org/10.1371/journal.pone.0040781 